Pesq. Vet. Bras. 31(5):430-440, maio 2011

\title{
Morfologia dos órgãos genitais masculinos e da cloaca da ema (Rhea americana americana) ${ }^{1}$
}

\author{
Tatiana C. Santos ${ }^{2^{*}}$, Joel A. Sousa ${ }^{3}$, Moacir F. Oliveira ${ }^{4}$, José M. Santos ${ }^{5}$, \\ Rogério C. Parizzi ${ }^{3}$ e Maria A. Miglino ${ }^{3}$
}

\begin{abstract}
Santos T.C., Sousa, J.A., Oliveira M.F., Santos J.M., Parizzi R.C. \& Miglino M.A. 2011. [Morphology of the male genital organs and cloaca of Rhea americana americana.] Morfologia dos órgãos genitais masculinos e da cloaca da ema (Rhea americana americana). Pesquisa Veterinária Brasileira 31(5):430-440. Departamento de Zootecnia, Universidade Estadual de Maringá, Av. Colombo 5790, Maringá, PR 87020900, Brazil. E-mail: tcsantos@uem.br

The rhea (Rhea americana americana) is a bird that belongs to the group of the Ratitas, order Rheiforme and family Rheidae. Macroscopic and microscopic morphology of the male genital organ (testes, epididymis, deferent ducts, and phallus) and the cloaca were analyzed in 23 emas, four chicken ( 2 weeks old), young ( 3 to 10 months old), and twelve adult ones (3 years old), from Cooperativa Emas do Brasil, RS and from CEMAS, Mossoró, $\mathrm{RN}$. The testis of rhea had elongated shape and were located inside coelomatic cavity, in dorsal region of abdominal cavity, with medium length and width of $7.6 \pm 1.2 \mathrm{~cm}$ and $2.6 \pm 0.7 \mathrm{~cm}$ at adult animals; $4.5 \pm 1.5 \mathrm{~cm}$ and $0.9 \pm 0.4 \mathrm{~cm}$ at young animals; and $0.8 \pm 0.3 \mathrm{~cm}$, and $0.2 \pm 0.1 \mathrm{~cm}$ at chicken. The testis were recovered by the tunica albuginea and its parenchyma had seminiferous tubules composed by spermatogenic epithelium and by sustentation cells, and also interstitial tissue, with interstitial endocrine cells, connective tissue and vessels. At the adult animals were observed all the cells from spermatogenic lineage, whilst at the youngs with 3 months the seminiferous tubules had a smale lumen with spermatogonia and undifferentiated sustentacular cells. The efferents ductus were composed by a cubic ciliated epithelium, while the epididimydis duct had a columnar epithelium. The epididymis was elongated and fusiform closely to medial testis board. The deferent duct had sinuous stretch at adult animals, rectilineae at young animal, convolute at its medium portion, decreasing its sigmoid shape at caudal portion, next to cloaca. The epithelium was pseudostratified ciliated, irregular lumen at adult animal, and circular at young animal, closely with urether. The cloaca was divided into three segments: coprodeum, urodeum and proctodeum. At urodeum the deferent ducts discharged into papillas at the ventral side wall, next to fibrous phallus's insertion. The phallus was a lymphatic fibrous organ, located at ventral wall, at the cloaca floor, and was composed by two portions: one rigid forked and twisted, and another simple spiraled and flexible, which normally was inverted. In forced exposition, the phallus had $14 \mathrm{~cm}$ in length. In a general way the Rhea genital organs shared the morphology from others birds, mainly those described to the ostrich.
\end{abstract}

INDEX TERMS: Genital organs, ratite, testis, epididymis, deferent duct, phallus, Rhea americana americana.

\footnotetext{
${ }^{1}$ Recebido em 5 de julho de 2010.

Aceito para publicação em 2 de fevereiro d 2011.

Parte da Dissertação de Mestrado do segundo autor.

2 Departamento de Zootecnia, Universidade de Maringá, Av. Colombo 5790, Maringá, PR 87020-900, Brasil. *Autor para correspondência: tcsantos@uem.br

${ }^{3}$ Faculdade de Medicina Veterinária e Zootecnia, Departamento de Cirurgia, Universidade de São Paulo (USP), Cidade Universitária, Av.
}

Prof. Dr. Orlando Marques de Paiva 87, São Paulo, SP 05508-270, Brasil.

4 Departmento de Ciencias Animais, Universidade Federal Rural do Semi-Árido (UFERSA), BR $110 \mathrm{Km} \mathrm{47,} \mathrm{Bairro} \mathrm{Presidente} \mathrm{Costa} \mathrm{e}$ Silva, Mossoró, RN 59625-900, Brasil.

5 Universidade Anhembi Morumbi, Rua Dr. Almeida Lima 1134, São Paulo SP 03164-000 e Faculdade de Medicina do ABC, Av. Príncipe de Gales 821, Santo André, SP 09060-650. 
RESUMO.- As características morfológicas, macroscópicas e microscópicas, dos órgãos genitais masculinos e da cloaca foram analisados em 23 emas, quatro filhotes (duas semanas), sete jovens (de três a oito meses) e doze adultos (três anos), provenientes da Cooperativa Emas do Brasil, RS, e do CEMAS, Mossoró, RN. Os testículos da ema possuem formato alongado e localizam-se na cavidade celomática, na região intra-abdominal dorsal, com comprimento e larguras médias de $7,6 \pm 1,2 \mathrm{~cm}$ e $2,6 \pm 0,7 \mathrm{~cm}$ nos adultos; $4,5 \pm 1,5 \mathrm{~cm}$ e $0,9 \pm 0,4 \mathrm{~cm}$ nos jovens; e $0,8 \pm 0,3 \mathrm{~cm}$, e $0,2 \pm 0,1 \mathrm{~cm}$ nos filhotes. O testículo está envolto pela túnica albugínea e seu parênquima possui túbulos seminíferos irregulares, compostos por epitélio espermatogênico e por células de sustentação, e pelo tecido intersticial, com as células endócrinas intersticiais, tecido conjuntivo frouxo e vasos. Nos adultos observaram-se todas as células da linhagem espermatogênica, enquanto nos jovens com 3 meses, os testículos apresentaram túbulos seminíferos com luz reduzidas, espermatogônias e células de sustentação indiferenciadas. Os ductos eferentes possuem um epitélio cúbico ciliado, enquanto no ducto epididimário o epitélio é columnar. O epidídimo apresentou-se alongado e fusiforme junto a margem medial do testículo. $O$ ducto deferentes apresentou trajeto sinuoso nos adultos, retilíneo nos jovens, convoluto na sua porção média, diminuindo seu formato sigmóide em sua porção caudal, próximo à cloaca. O epitélio é pseudoestratificado e reveste a luz irregular nos adultos e circular nos jovens, mantendo proximidade com o ureter. A cloaca dividiu-se em três segmentos: o coprodeu, o urodeo e o proctodeo. No urodeu os ductos deferentes desembocaram em papilas na parede ventro-lateral, próximo a inserção do falo fibroso. O falo é um órgão fibroso linfático, localizado na parede ventral, no assoalho da cloaca, e apresentou duas porções: uma rígida bifurcada e contorcida, e outra simples espiralada e flexível, a qual normalmente esteve invertida. Em exposição forçada, o falo teve $14 \mathrm{~cm}$ de comprimento. De forma geral os órgãos reprodutores das emas compartilharam da morfologia de outras aves, principalmente aquelas descritas para os avestruzes.

TERMOS DE INDEXAÇÃO: Órgãos genitais, testículo, epidídimo, ducto deferente, falo, ema, Rhea americana americana.

\section{INTRODUÇÃO}

A ema, Rhea americana americana, uma ave silvestre típica da fauna brasileira e de alguns países da América do Sul, habita regiões de campo e cerrados e apresenta extrema rusticidade e adaptabilidade (Romer \& Parson 1985). A espécie mais indicada para criação no Brasil é Rhea americana americana, devido a sua maior facilidade de adaptação em cativeiro, encontrada no norte do Pará, Nordeste, Centro-Oeste e Sudeste. A Rhea americana intermédia pode ser encontrada em Santa Catarina, no sul do Paraná e no Rio Grande do Sul e Rhea americana albensens, no sudoeste do Mato Grosso do Sul (Dunning \& Belton 1993). A ema pode atingir de 1,34-1,70m de altura. O macho é maior que a fêmea e diferencia-se por um colar de penas escuras na base do pescoço, região anterior e parte mediana do dorso, podendo atingir até $34,4 \mathrm{~kg}$. As fêmeas podem atingir $32 \mathrm{~kg}$ e sobreviver até os 40 anos de idade e pesar aproximadamente $35 \mathrm{~kg}$ (Olson 1983, Sick 1985).

Sobre os aspectos reprodutivos da espécie, as estações de postura podem variar, dependendo do clima da região onde se encontra o criatório, de setembro a fevereiro, no sul do país e de julho a setembro, nas demais regiões. Normalmente, os ovos são chocados pelos machos, os quais permanecem extremamente agressivos durante os primeiros dez a quinze dias após a eclosão, com o objetivo de proteger a prole (Dunning \& Belton 1993).

Os estudos referentes à morfologi da ema são escassos, principalmente, no que diz respeito aos órgãos genitais masculino. Hicks-Alldredge (1996) cita que há poucas pesquisas a respeito da reprodução de ratitas e a maior parte do conhecimento acerca dos princípios básicos de fisiologia reprodutiva e de tecnologia de incubação tem sido extraída de outras aves, principalmente galinhas (Gallus gallus domesticus).

Desta forma, objetivou-se descrever a morfologia dos órgãos genitais masculino da ema (Rhea americana americana), testículos, epidídimos, ductos deferentes, falo e a cloaca. Com este objetivo, estes órgãos foram analisados em emas filhotes, jovens e adultas, macroscopicamente $e$ por microscopia de luz, a fim de descrever suas principais características macroscópicas e a estrutura de cada órgão e de seus segmentos.

\section{MATERIAL E MÉTODOS}

Para descrição morfológica do aparelho genital masculino da ema (Rhea americana americana), foram utilizados conjuntos de órgãos de 23 emas, sendo 12 adultas (idade aproximada de 3 anos, em fase reprodutiva), 7 jovens (de 3-10 meses) e 4 filhotes (20 dias).

As emas adultas foram abatidas em abatedouro comercial e as vísceras colhidas durante o processo de evisceração. Os animais abatidos pertenciam a Cooperativa Emas do Brasil LTDA (Inscrição 096/3042653, CNPJ 06923872/00011-08). As demais amostras foram fornecidas pelo Centro de Multiplicação de Animais Silvestres CEMAS-UFERSA, Mossoró, RN (Registrado junto ao IBAMA como Criador Científico sob o № 1/24/ 92/0040-4). Este projeto possui Certificado de aprovação pela comissão de Bioética da Faculdade de Medicina Veteriária e Zootecnia da Universidade de São Paulo, protocolo 1107/2007.

Os órgãos genitais masculinos (testículos, epididimos, ductos deferentes e falo) e a cloca foram analisados a fresco quanto à forma, coloração, posição e sintopia. Os testículos foram mensurados com paquímetro digital e obtido o comprimento (eixo do pólo cranial ao caudal) e a largura (eixo da margem lateral à margem medial). As médias obtidas foram analisadas pelo programa SAS por comparação de médias a $5 \%$ de probabilidade (SAS 1999).

Fragmentos dos órgãos genitais (testículos, epidídimo, ducto deferente, cloaca e falo) foram colhidos e fixados por imersão em solução de formaldeido $10 \%$ PBS $0,1 \mathrm{M}, \mathrm{pH} 7,4$ para microscopia de luz. As amostras foram processadas na rotina histológicas e incluidas em Paraplast $₫$ (Leica $₫$, Germany) ou em Historesina ${ }^{\circledR}$ (Sigma, Oxford, USA). Os blocos de paraplast 
foram cortados com $5 \mu$ de espessura, corados em Hematoxilina/Eosina (HE), Tricrômio de Masson e realizada reação para o ácido periódico de Schiff. Os blocos de historesina foram seccionados com $1 \mu \mathrm{m}$ de espessura e corados com Hematoxilina/floxina (HF). Os cortes foram analisados em microscópio de luz (Olympus BX 60, Tókio, Japão).

Os termos adotados estão de acordo com a Nomina Anatômica Avium (Baumel et al. 1979).

\section{RESULTADOS}

A ema possui um par de testículos alongados, com dois pólos (cranial e caudal) e duas margens (medial côncava e lateral convexa), conferindo-lhes a forma de um feijão. A fresco os testículos nos animais adultos, em atividade sexual, apresentam coloração creme, enquanto que nos animais mais jovens apresentam coloração variando de tons avermelhados a marron (Fig.1).

Localizados na cavidade celomática, ventralmente aos rins, os testículos estão separados um do outro pela alça mesentérica e relacionam-se craniomedialmente com as glândulas adrenais e medialmente com a veia cava caudal. Nos filhotes (três semanas de vida), o testículo direito está aderido à parede da veia cava e apresenta-se mais cranial do que o testículo esquerdo, que por sua vez, apresenta-se ligeiramente maior que o testículo direito (Fig.1B). Os valores médios do comprimento e da largura dos testículos direito e esquerdo não apresentaram diferenças significativas $(P>0,05)$ entre si (Quadro1).

Com relação aos aspectos microscópicos, os testículos estavam envoltos por uma cápsula denominada túnica albugínea, constituida por fibras colágenas, organizadas paralelamente, caracterizando tecido conjuntivo denso, e possuiu um estrato vascular profundo, próximo ao parên-
Quadro 1. Comprimento e largura (média \pm desvio) dos testículos direito (TD) e esquerdo (TE) de emas. São Paulo, 2010

\begin{tabular}{cccccc}
\hline \multirow{2}{*}{ Animal } & \multicolumn{2}{c}{ Comprimento $(\mathrm{cm})$} & & \multicolumn{2}{c}{ Largura $(\mathrm{cm})$} \\
\cline { 2 - 3 } \cline { 5 - 6 } & TD & TE & & TD & TE \\
\hline Adulto $(\mathrm{n}=12)$ & $7,61 \pm 1,22$ & $7,55 \pm 1,15$ & & $2,61 \pm 0,83$ & $2,57 \pm 0,62$ \\
Joven $(\mathrm{n}=10)$ & $4,14 \pm 0,65$ & $5,04 \pm 1,02$ & & $1,46 \pm 0,25$ & $1,62 \pm 0,47$ \\
Filhote $(\mathrm{n}=4)$ & $0,75 \pm 0,7$ & $0,80 \pm 0,18$ & & $0,23 \pm 0,05$ & $0,26 \pm 0,05$
\end{tabular}

quima do testículo. Não foram observados septos de tecido conjuntivo, partindo da albugínea, em direção ao parênquima, tampouco condensação mediastinica.

O parênquima dos testículos esteve constituído por túbulos seminíferos e pelo compartimento intersticial intertubular. Os túbulos seminíferos apresentaram-se como tubos enovelados de formato irregular, constituídos por um epitélio germinativo estratificado, envolvido por uma bainha de tecido conjuntivo, formado por camadas de fibroblastos (Fig.2A). O epitélio seminífero consistiu de dois tipos celulares: as células de sustentação e as células do epitélio seminífero, que constituem a linhagem espermatogênica. As células de sustentação apresentaram núcleo basal e irregular, tendendo a piramidal. As células da linhagem germinativa em plena atividade compreenderam: as espermatogônias, os espermatócitos primários, os espermatócitos secundários, as espermátides e os espermatozóides maduros. As espermatogônias são células basais arredondadas com núcleos arredondados e basais. Os espermatócitos são células arredondadas, com núcleo arredondado e cromatina frouxa, na porção média da camada germinativa. Já as espermátides possueam cromatina mais condensada e alongada, núcleo e citoplasma proporcionalmente menores, que aqueles dos espermatóci-
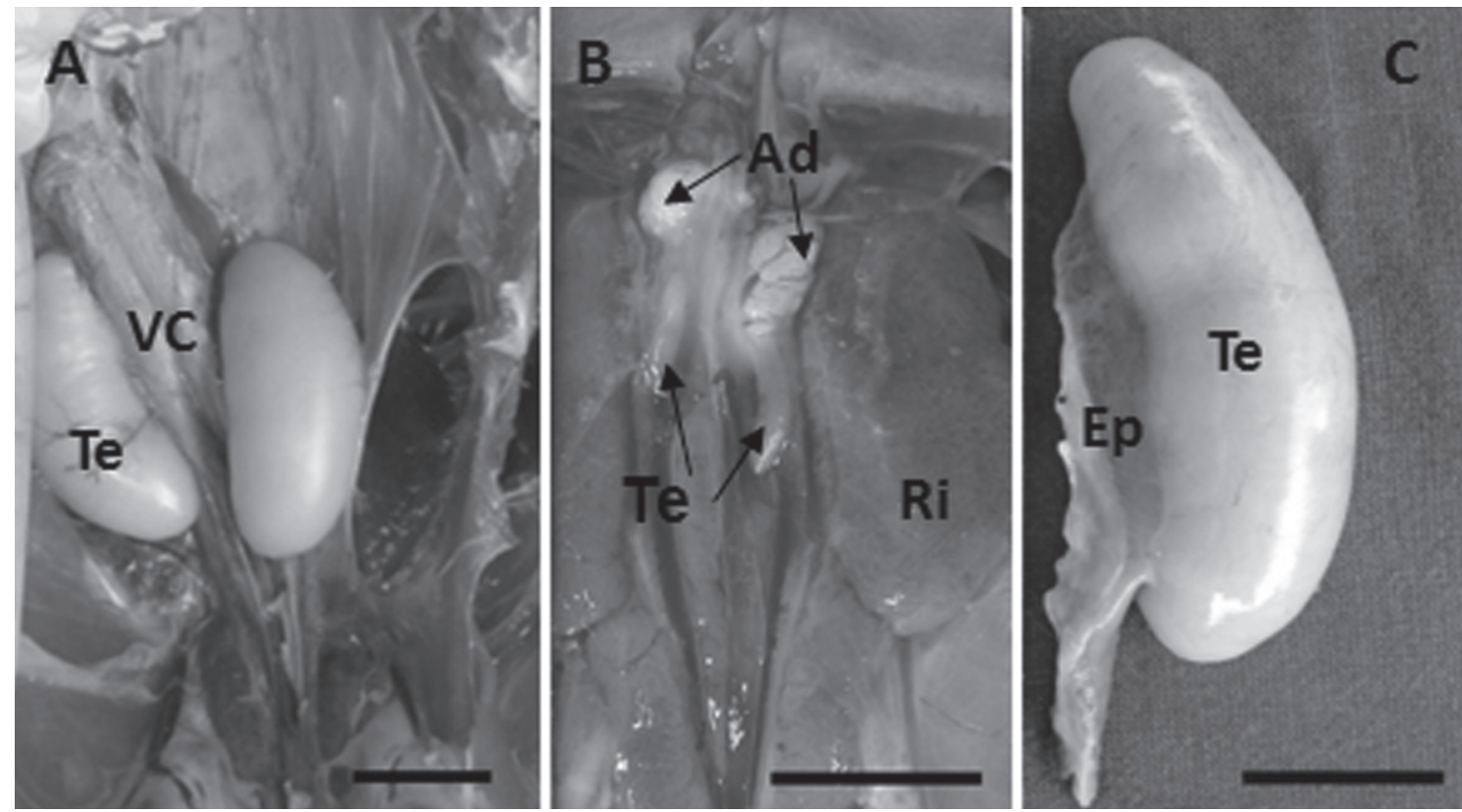

Fig.1. (A) Vista ventral dos órgãos reprodutores de ema na cavidade celomática em adulto e (B) filhote. Notar a posição do testículo (Te) e sua relação com a veia cava (VC), glândulas adrenais (Ad) e epidídimo (Ep). Barras: (A-C) $3 \mathrm{~cm}$ e $(\mathbf{B}) 1 \mathrm{~cm}$. 

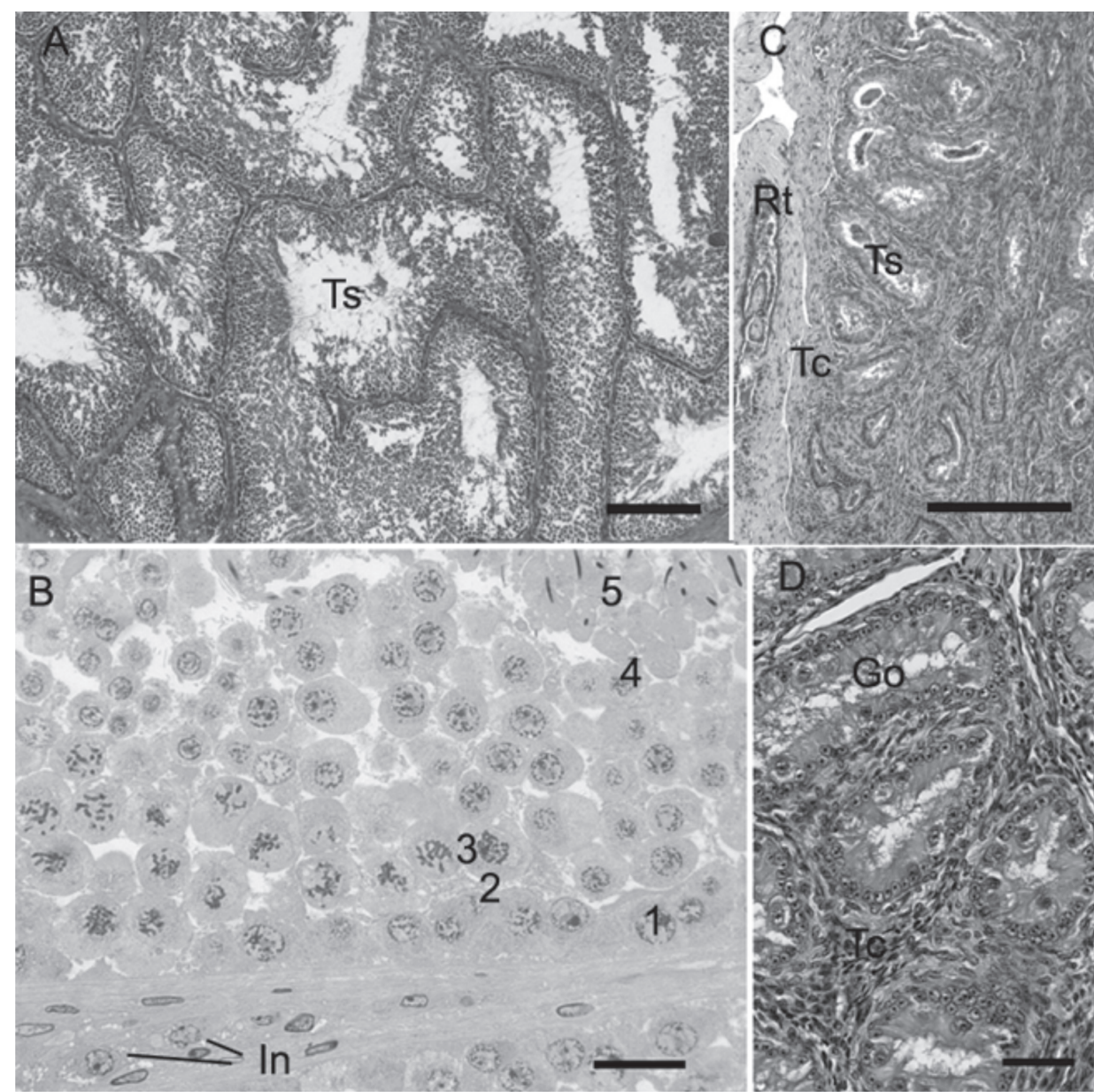

Fig.2. Túbulos seminíferos do testículo de ema adulta $(\mathbf{A}, \mathbf{B})$ e jovem com 3 meses (C,D). Notar a configuração irregular dos túbulos seminíferos (Ts) nos adultos (A) e o início de sua luminação em jovens (C,D). Espermatogônias tipo I e II (1-2), espermatócito (3), espermátide arredondada (4), espermátides alongadas (5), tecido conjuntivo (TC), rede testicular (Rt), células intersticiais (In). (A,B, D) Paraplast, HE. (B) Historesina, HF. Barras: (A) $1 \mathrm{~mm}$, (B) $20 \mu \mathrm{m}$, (C) $200 \mu \mathrm{m}$, (D) $50 \mu \mathrm{m}$.

tos. Estas células formaram cordões em direção à luz do túbulo seminífero e apresentaram citoplasma arredondado ou alongado, à medida que se aproximaram da luz do túbulo. Nas emas adultas, em estágio reprodutivo ativo, todas estas células foram identificadas e o lúmen esteve repleto de espermatozóides (Fig.2A-C). Os espermatozóides possuiam núcleo alongado e condensado, com forma de uma vírgula ao corte e cauda alongada, normalmente livres, na luz do túbulo.

Entre os túbulos seminíferos, o compartimento intersticial esteve compostos por tecido conjuntivo frouxo e células endócrinas intersticiais, ou células de Leydig. As células endócrinas intersticiais ocuparam o maior espaço entre os túbulos seminíferos e foram identificadas pelo núcleo arredondado e o citoplasma eosinófilo, com vacúolos (Fig.2C). No tecido conjuntivo do interstício ainda foram observados vasos sanguíneos, fibroblastos e fibras colágenas, identificadas na coloração de tricrômio de Masson.

As características histológicas dos testículos de emas adultas, em fase reprodutiva, e das jovens, com idade em torno de 10 meses, foram semelhantes. Já nas emas jovens, com 3 meses de idade idade (testículos com comprimento médio de $1,8 \mathrm{~cm}$ ), os testículos apresentaram túbulos seminíferos enovelados, compostos por células de sustentação e espermatogônias. Estes túbulos apresentaram luz reduzida, em quase todos os cortes observados. As células de sustentação possuiam núcleos arredondados, formato prismático e citoplasma eosinófilo, enquanto os gonócitos possuiam núcleos maiores e arredondados, algumas vezes com citoplasma globoso, destacados da membrana basal, as quais foram identificadas como espermatogônias (Fig.2D).

Macroscopicamente, o epidídimo apresentou-se alongado e fusiforme, inserido na margem dorsomedial do testículo (Fig.1C). Sua extremidade cranial possuia relação sintópica com a cápsula da glândula adrenal e, dorsalmente, com a veia cava caudal. Na sua porção caudal, emergiu o ducto deferente, que seguiu em direção a cloaca. Nos fiIhotes, geralmente, o epidídimo estava pouco desenvolvido, sendo difícil sua identificação macroscópica. 

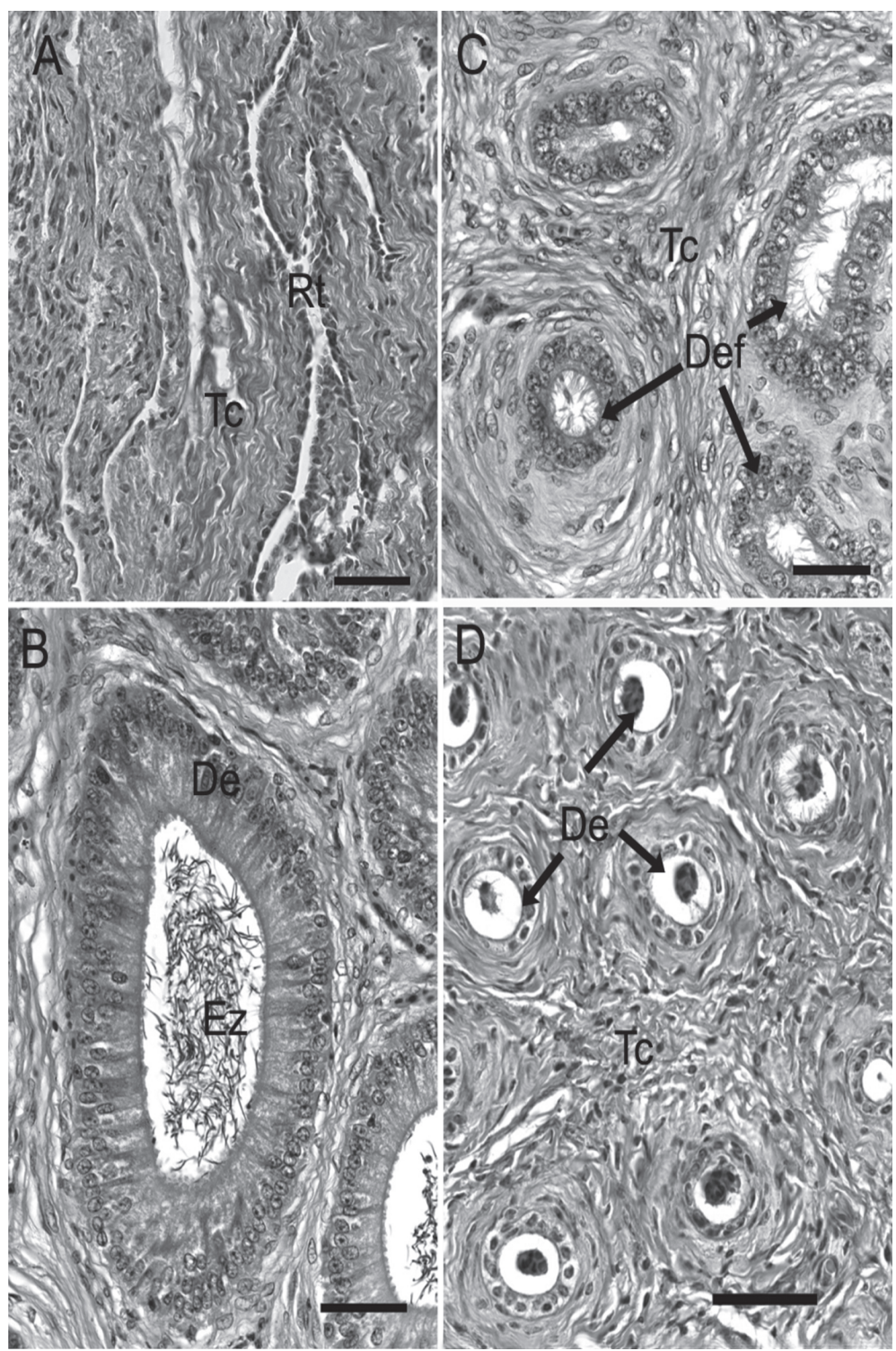

Fig.3. (A) Rede testicular (Rt) formada por ductos irregulares, revestidos por epitélio cúbico simples, na transição entre testículo e epidídimo. (B) Ductos eferentes (Def) com epitélio cúbico e estereocílios. (C) Ducto epididimário com epitélio pseudoestratificado, envolto por tecido conjuntivo. Notar os espermatozóides (Ez) na luz e os vasos sanguineos (setas). (D) Epidídimo de ema jovem (3 meses), com ducto epididimário (De) revestido por epitélio cúbico simples. tecido conjuntivo (TC). (B,C) HE, (A, D) Tricrômio de Mas-son. Barras: $40 \mu \mathrm{m}$.
Entre o testículo e o epidídimo, uma faixa de tecido conjuntivo conteve os ductos da rede testicular, posicionada extratesticular. Estes ductos apresentaram epitélio cúbico simples e formato irregular (Fig.3A). Já os ductos eferentes possuem luz irregular, ou circular, e estão revestidos por um epitélio pseudoestratificado cilíndrico baixo ciliado. Os cortes irregulares apresentam luz proporcionalmente maior que aqueles com luz circular e pequenas pregas de mucosa. Estes ductos estavam envolvidos por abundante tecido conjuntivo (Fig.3B).

O ducto epididimário enovelado esteve revestido por tecido conjuntivo frouxo, por onde passaram os vasos sanguíneos. Nos adultos, apresentou epitélio pseudoestratificado, composto por dois tipos celulares: as células cilíndricas alongadas e as basais. As células cilíndricas foram estreitas, com citoplasma levemente basofílico e estendem-se da membrana basal à luz, possuindo núcleos cilíndricos alongados, dispostos no terço médio da célula. As células basais mantiveram contato apenas com a mem- brana basal, com núcleo mais escuro e citoplasma alongado. Nos animais adultos ou em jovens, a partir dos 10 meses, observaram-se espermatozóides na luz dos ductos epididimários (Fig.3B,C).

Nos jovens, com 3 meses de idade, o ducto epididimário e eferente apresentaram epitélio cúbico simples ciliado. $O$ diâmetro do ducto foi menor que nos adultos e não se observaram espermatozóides na luz. Em alguns cortes histológicos, células estavam na luz do ducto (Fig.3D). O tecido conjuntivo, entre as voltas do ducto epididimário, possuia fibras colágenas que se organizaram ao redor do ducto, formando uma faixa mais densa, e apresenta-se frouxo no geral, com vasos sanguíneos.

Macroscopicamente, observou-se que o ducto deferente in situ apresentou um trajeto sinuoso, em "ziguezague" (Fig.4A), convoluto na porção média, diminuindo o enovelamento na porção distal, e tornando-se retilíneo próximo a cloaca, formando a parte reta do ducto deferente. Na cavidade celomática, o ducto deferente correu paralelo à linha 
média e seguiu medialmente ao ureter. Desembocou na parede dorsolateral da cloaca, na região dorsal do urodeo, em uma dilatação representada por uma curta papila do ducto deferente. Cada papila do ducto deferente representou uma projeção cônica da parede do urodeo, imediatamente ventral e em média a $1 \mathrm{~cm}$ do óstio do ureter (Fig.4B).

Nas emas adultas, a luz do ducto deferente foi irregular e a mucosa esteve composta por epitélio pseudoestratificado, com espermatozóides na luz do ducto. O tecido conjuntivo moderadamente denso formou uma faixa estreita ao redor do ducto (Fig.4C,D). Enquanto que nos jovens (3 meses) o ducto não está enovelado e a luz é ovalada ao corte, com epitélio pseudoestratificado baixo e sem espermatozóides.

A cloaca apresentou formato de cone e esteve dividida em três segmentos: o coprodeo (recebe a desembocadura do reto), o urodeo (desembocam os ductos deferentes e ureteres) e o proctodeo (maior porção da cloaca, região mais caudal, em que se projeta o falo).
O urodeo foi o menor dos três compartimentos da cloaca e esteve separado cranialmente do coprodeo, pela prega coprourodeal e caudalmente do proctodeo, pela prega uroproctodeal. O proctodeo foi o mais caudal e o maior compartimento da cloaca. Neste compartimento, ventralmente, se localizou o órgão copulatório, o falo. Microscopicamente o epitélio da mucosa da cloaca variou de cilíndrico simples a pavimentoso estratificado. Na região do urodeo apresentou um epitélio cilíndrico simples, com o pólo apical repleto de grânulos de secreção PAS+, revestindo pequenas pregas de tecido conjuntivo frouxo. Na base do falo proximal, a mucosa tornou-se estratificada, sobre uma espessa faixa de tecido conjuntivo frouxo e uma musculatura lisa, com vasos sanguíneos (Fig.5C).

O falo estava localizado na parede ventral, no assoalho da cloaca, na região do proctodeo, ligeiramente à esquerda da linha média. Apresentou-se como um órgão fibroso linfático, constituído por duas porções: uma proximal, rígida,

Fig.4. (A) Fotografia dos ductos deferentes (Dd) enovelados de ema adulta in situ. (B) Vista dorsal da face ventral da cloaca evertida, com o falo proximal exposto, para visualização das papilas do ducto deferente $(\mathrm{PI})$ na base do sulco do falo (Sf). (C) Porção média do ducto deferente de ema jovem (3 meses). Notar o tecido conjuntivo (Tc) moderadamente denso ao redor do ducto deferente e seu epitélio baixo. (D) Epitélio pseudoestratificado (Ep) da porção média do ducto deferente de ema adulta com espermatozóides (Ez) na luz. HE, Barras: (A,B) $1 \mathrm{~cm},(C, D) 40 \mu \mathrm{m}$.

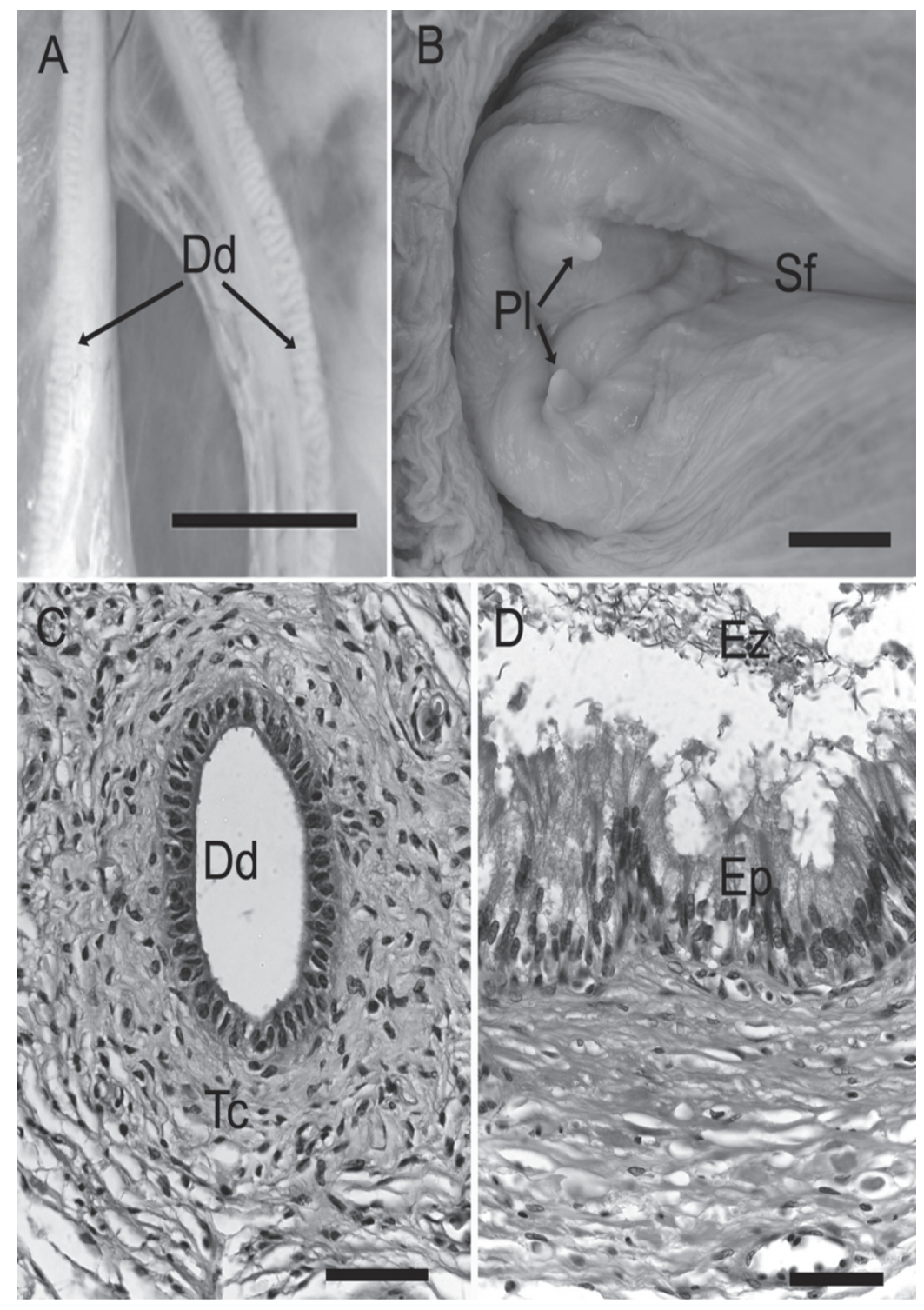




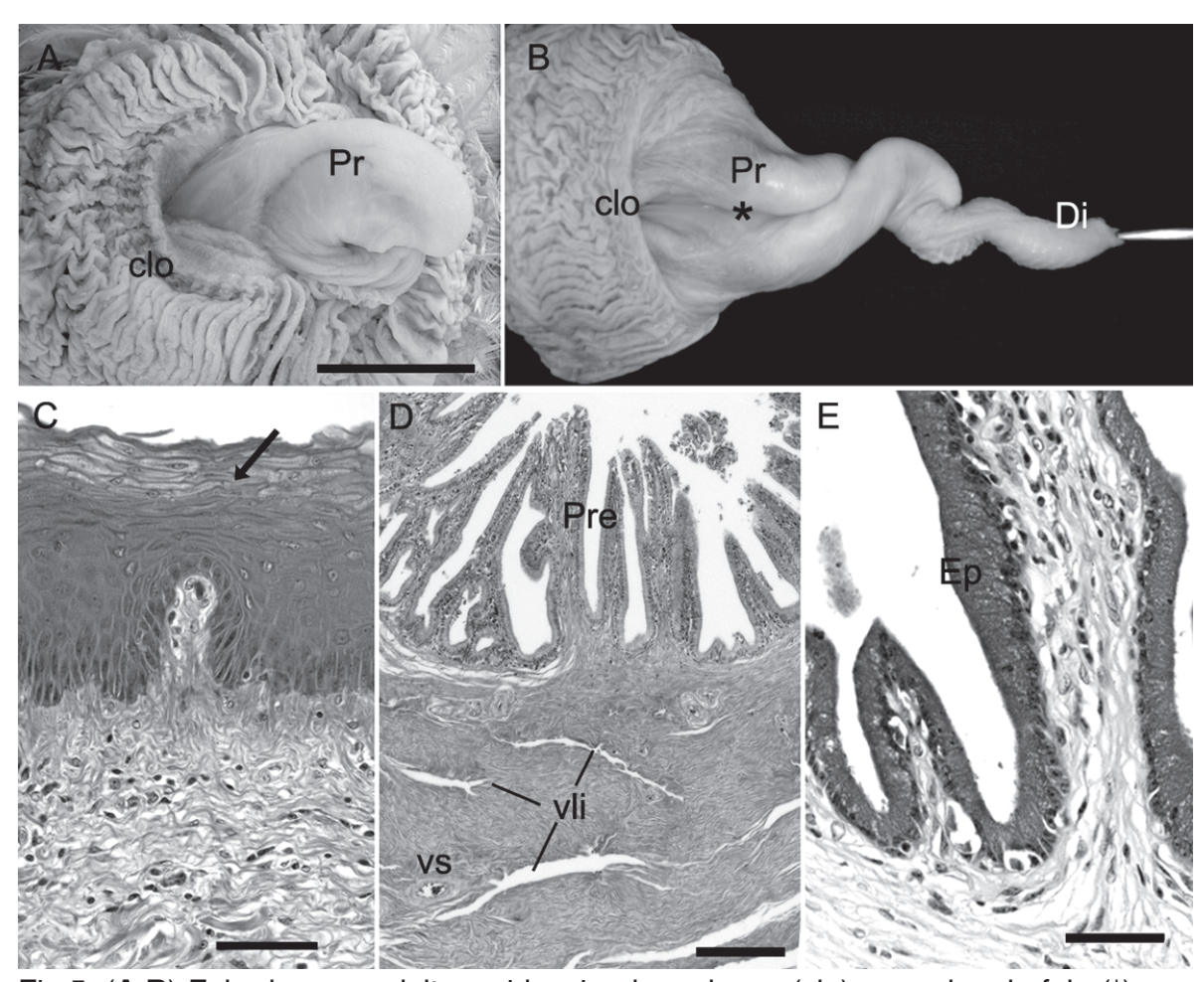

Fig.5. (A,B) Falo da ema adulta, evidenciando a cloaca (clo) e o sulco do falo (*) proximal (Pr) e distal (Di), respectivamente. Barras: $3 \mathrm{~cm}$. (C) Mucosa da cloaca com epitélio estratificado (arrow). (D,E) Pregas da mucosa (Pre) da porção distal do falo flexível invertido, revestidas por epitélio cilíndrico (Ep) com conteúdo PAS+, dispostas sobre o tecido conjuntivo rico em fibras colágenas e com muitos vasos linfáticos (vli) e sanguíneos (vs). (C,D) Tricrômio de Masson, (E) PAS. Barras: (C,E) 40 $\mu \mathrm{m}$, (D) $100 \mu \mathrm{m}$.

bifurcada e contorcida e outra distal, tubular, espiralada e flexível. A porção rígida proximal do falo, a mais espessa, possuiu um arcabouço cartilaginoso que a sustentou, composto por duas porções rígidas, as quais se curvaram ventral e lateralmente (para a direita), rodando sobre si, de forma que este conjunto assumiu forma espiralada (Fig.5A). As duas extremidades destas porções rígidas ficaram sobrepostas na extremidade distal do falo. Ventralmente a este, no falo em repouso, localizou-se a porção flexível do falo, que caracteristicamente estava flácida. Esta porção foi formada por um tubo que ficou invertido ventralmente, sob a porção rígida do falo. Este tubo inseriu-se ventralmente na porção rígida e, em repouso, apresentou-se tortuoso. Em "ereção", ou exposição forçada, a porção mais distal deste tubo foi exposta por entre os dois "corpos cartilaginosos" e constituiu a extremidade livre do falo (Fig.5B).

Em exposição forçada da porção flexível, o falo de emas adultas apresentou, em média, $14 \mathrm{~cm}$ de comprimento $(n=6)$. Em repouso, a porção flexível esteve alojada no interior da sua base (porção proximal), formando volumosas massas teciduais, em formato esférico, na base ventral do falo. O falo apresentou, ainda, dois pares de músculos, situados na sua porção ventral: o músculo levantador do falo e o músculo retrator do falo. Na porção dorsal do falo e ventral à cloaca encontra-se um sulco, que se estendeu desde a porção proximal do falo até o ápice da porção distal do mesmo, responsável por carrear o sêmen até a cloaca da fêmea (Fig.5B).

Microscopicamente, o falo proximal esteve revestido por um epitélio pavimentoso estratificado, apoiado em uma camada de tecido conjuntivo. A porção distal, intromitente, esteve composta por grande quantidade de tecido conjuntivo moderadamente modelado, rico em fibras colágenas, entremeadas por vários vasos linfáticos. A mucosa invertida compõe uma luz interna quando o órgão está em repouso, que apresenta pregas para a luz, revestidas por um epitélio colunar simples com células contendo grânulos citoplasmáticos PAS+ (Fig.5D,E).

\section{DISCUSSÃO}

A organização morfológica dos órgãos genitais masculinos da ema foi descrita macro e microscopicamente. De forma geral, a disposição e a localização dos órgãos assemalhan-se com o citado para outras espécies de aves. Os órgãos genitais masculinos são representados por dois testículos, dois epidídimos, dois ductos deferentes, e pelo órgão copulatório, o falo, e pela cloaca. Porém, os resultados obtidos demonstram algumas características próprias da ema, como, por exemplo, um falo intromitente bem desenvolvido.

Nos animais jovens e adultos analisados observou-se que a ema possui um par de testículos, com um formato 
alongado, envolto pela túnica albugínea, com forma de um feijão alongado. Este formato parece ser comum entre as aves, uma vez que nas espécies descritas o formato de um feijão alongado é recorrente (Lake et al. 1981). Nos filhotes e jovens com até 3 meses, os órgãos reprodutores estão pouco desenvolvidos, com testículos pequenos, epidídimo aderido na face dorsomedial, ductos deferentes retilíneos e falo reduzido.

Nos machos, de todas as espécies de aves, os testículos localizam-se no interior do corpo e não no escroto como em alguns mamíferos. São proporcionalmente maiores do que os dos mamíferos (em relação ao peso corporal) e em muitas espécies há assimetria bilateral, sendo a gônada esquerda maior do que a direita (Lake 1981). Nas aves domésticas estão localizados craniais aos rins e fixados à parede dorsal interna do corpo por uma dobra do peritônio. Essa posição dos testículos confere as aves a características de realizarem espermatogênese a uma temperatura corporal interna de $40-42^{\circ} \mathrm{C}$ (Froman \& Kirby 2004).

No presente trabalho, em emas adultas, em estágio reprodutivo, o valor médio de $7,5 \mathrm{~cm}$ de comprimento e $1,3 \mathrm{~cm}$ de largura, demonstra o grande desenvolvimento deste órgão na espécie. Porém, deve ser considerado neste ponto que as emas são proporcionalmente maiores que as aves domésticas, podendo atingir $34 \mathrm{~kg}$. Nas emas, o testículo direito apresentou-se ligeiramente mais cranial que o esquerdo, tanto nos animais jovens quanto nos adultos. Porém, com relação ao tamanho, não houve diferenças significativas $(P>0,05)$, entre a largura e comprimento dos testículos direito e esquerdo. Friedman (1927) encontrou em 60 espécies de aves estudadas que o testículo esquerdo era maior que o direito, mas em outras 104 espécies, os testículos eram similares em tamanho.

O tamanho, forma e posição dos testículos podem variar consideravelmente dependendo do ciclo do estágio reprodutivo em aves (Bell \& Freeman 1971, Nickel et al. 1977, Lake et al. 1981, King 1986, Benez 1998). Aves em estágio reprodutivo possuem aumento de tamanho dos testículos, devido ao incremento no tamanho dos túbulos seminíferos e do número de células intersticiais e, nestes períodos, o peso do testículo representa em torno de $1 \%$ do peso da ave (Lake et al. 1981).

A coloração dos testículos nos filhotes e jovens assemelha-se a cor dos rins, enquanto que nos adultos a coloração dos testículos é mais clara em tons de creme. Lake (1957) relata que a cor do testículo pode variar de acordo com sua fase sexual. Durante o período sexualmente ativo, geralmente é esbranquiçado, porém fora da estação reprodutiva, reduz seu tamanho e sua coloração é intensificada aparentando-se marrom claro.

Nas aves, os túbulos seminíferos dos machos imaturos são delineados por uma única camada de células de Sertoli e espermatogônias pedunculares, enquanto que nos machos adultos os túbulos apresentam formas irregulares, delineados por um epitélio germinativo de múltiplas camadas (Froman \& Kirby 2004). Esse padrão foi observado no material de emas analisado aos 3 meses de idade.
A idade de maturidade sexual é muito particular para cada espécie de ave. Os testículos de ema com 10 meses (testículos com média de 4,6cm de comprimento) possuíam todas as células da linhagem espermática com espermatozóide na luz, sugerindo que estas já poderiam ser consideradas em maturidade sexual. Codenotti \& Alvarez (1997) citam que os filhotes de ema chegam a sua maturidade sexual em torno dos dois anos de idade. No entanto, Giannoni (1996) observou que filhotes machos nascidos no início da estação reprodutiva, atingem a maturidade sexual em um ano de idade. Como as amostras de emas jovens provieram do Rio Grande do Norte, os resultados sugerem que as emas criadas nessa região geográfica iniciam a produção de espermatozóides a partir de 10 meses de idade.

As características histológicas dos testículos e epidídimos de emas são comuns ao de outras aves. Os resultados obtidos deste estudo foram similares aos descritos em aves domésticas e avestruzes (Gray 1937, Hodges 1974, Macari \& Junior 2000, Simões et al. 2004). Já nas emas sexualmente imaturas, os testículos analisados já apresentavam lúmen, em praticamente todos os túbulos, e, apesar da altura do epitélio não ter sida analisada quantitativamente, as imagens obtidas sugerem um epitélio em torno de $30 \mathrm{~mm}$. Em filhotes de galo doméstico os túbulos seminíferos já apresentam lúmen com 2 semanas de vida e o epitélio possui em média 50mm (Marvan 1968). Também Randal e Reece (1996) comentam que testículos imaturos, de galos jovens, com 42 dias, mostram túbulos seminíferos alinhados por uma camada única de células intersticiais e espermatogônias e espermatócitos primários são encontrados com aproximadamente 6 semanas de idade.

O testículo da ema separa-se do epidídimo por uma faixa de tecido conjuntivo, que possui ductos diferenciados pelo epitélio cúbico simples e pelo formato irregular ao corte. Estes ductos foram caracterizados como a rede testicular, que está posicionada extra-testicular. Ductos com luz reduzida, com forma irregular e com formato circular, revestidos por um epitélio cúbico simples ciliado, também foram observados nesta região e caracterizados como ductos eferentes. Nos patos, Aires (1982) comenta que a rede testicular, localizada na porção interna, dorsomedialmente do testículo, liga os túbulos seminíferos com toda a região do epidídimo, constituído por parte intratesticular, intracapsular e extratesticular.

A fertilidade em aves é um processo complexo que depende, sobretudo, do sucesso completo de um número de passos cruciais de espermatogênese, maturação extragonadal e sobrevivência e função do espermatozóide dentro do oviduto da fêmea (Froman \& Kirby 2004). Na maioria das aves, as estratégias reprodutivas do macho envolvem a rápida produção, maturação e transporte dos espermatozóides através do trato reprodutivo, associado com uma capacidade limitada de estoque destes por longos períodos nos ductos genitais (Clulow \& Jones 1982). Estas características nas aves levaram a configuração de 
epidídimos menos desenvolvidos e ductos deferentes com capacidade para armazenar espermatozóides.

Com relação ao epidídimo, Budras \& Meier (1981) descreve que em ratitas o epidídimo é mais longo nos filhotes do que o testículo e que nos adultos percorre todo o comprimento do testículo. Nas emas jovens analisadas foi observado um epidídimo difícil de visualizar e pouco desenvolvido. Já nas emas adultas e jovens com 10 meses o epidídimo é menor que o testículo em comprimento, possui um formato alongado e fusiforme bem evidente na margem medial do testículo, ao contrário das aves domésticas (King \& McLelland 1984, Lake 1986), em que geralmente o epidídimo apresenta-se como um corpo afilado pouco visível, aumentando gradativamente de tamanho na fase reprodutiva e que ocupa todo o comprimento dorsomedial do testículo.

As características histológicas do ducto epididimário das emas adultas e jovens são similares as demais aves, incluindo os avestruzes e emús (Aire \& Soley 2000, Ozegbe et al. 2010). Aires (1979) relata que a região epididimal nas aves domésticas, consiste de muitos túbulos e ductos conectados na porção medial dos testículos, o qual comprime a rede testicular proximal e distal do ducto eferente, formando uma curta conexão ao ducto do epidídimo.

Em codornas domésticas (Artoni et al. 1999), galo (Tingari 1971) e perus (Hess et al. 1976) os ductos eferentes constituem a maior fração de todo o volume epididimário. A característica de luz irregular com projeções para a luz descrita em codornas (Artoni et al. 1999) e em patos (Simões et al. 2004), tambem foram observadas em emas adultas em fase reprodutiva, porém de forma menos procunciada do que descrito para estas espécies.

A continuação do ducto epididimário é o ducto deferente. Este estende-se do epidídimo até a cloaca, local em que se abre latero-ventralmente, na região do urodeo, próximo ao ureter, como descrito por Marvan (1968). O trajeto sinuoso do ducto deferente descrito por Munro (1938) e Viegas (2004), saindo do epidídimo até próximo à cloaca e antes de desembocar na cloaca tornar-se mais retilíneo, terminando em uma curta papila, também é comum aos resultados macroscópicos em emas adultas.

O ducto deferente nas emas adultas apresenta-se revestido por tecido pseudoestratificado com lúmen pregueado, repleto de espermatozóides, sugerindo que nesta espécie estes ductos possuem funções de armazenamento de espermatozóides. Relatos esses também encontrados nos galos (Lake 1957, Tingari 1971), nas codornas (Viegas 2004) e nos perus (Hess et al. 1976).

Em galos adultos, em fase reprodutiva, o ducto deferente está normalmente túrgido, esbranquiçado e repleto de sêmen, podendo armazenar em aves com $2,5 \mathrm{~kg}$, em ambos os ductos, até $0,89 \mathrm{ml}$ de sêmen. Nas aves inativas sexualmente o ducto está reduzido e contêm uma secreção aquosa, já durante a atividade sexual a concentração de espermatozóides no ducto deferente é semeIhante a do ducto epididimário (Lake et al. 1981). Também nas codornas domésticas, variedade italiana citou-se que a luz dos ductos deferentes freqüentemente estoca gran- de quantidade de espermatozóide e fluído (Viegas 2004). Para emas cita-se em machos em estação reprodutiva um volume de ejaculado de $0,68 \pm 0,146 \mathrm{~mL}$ com concentração de 3,29 $\pm 1,33 \times 10^{9}$ espermatozóides/mL (Goés 2004), em emús 0,61 mL (Malecki et al. 1997) e em avestruzes 0,64mL (Hemberger et al. 2001).

Com relação a morfologia nos jovens imaturos, acredita-se que com a maturação sexual o epitélio aumente de tamanho, formando as células cilíndricas e promovendo o enovelamento do ducto.

Os ductos deferentes da ema desembocam em papilas na cloaca. Esta consiste de três compartimentos: coprodeo, urodeo e proctodeo igual aos encontrados em outras aves (Komárek 1970, King \& McLelland 1984, King 1986). Na dissecação das peças a prega que separa a porção final do reto e o coprodeo é bem definida e facilmente identificável.

A cloaca na ema se diferencia em alguns aspectos da galinha, como as divisões dos compartimentos bem definidas. No galo o limite entre o reto e o coprodeo é distintamente demarcado, neste ponto, por uma súbita expansão do calibre (Bakst 1998). A ema parece estar entre as poucas espécies que, de fato, possuem uma verdadeira prega entre o reto e o coprodeo. Na ema, a abertura da cloaca é marcada por uma mancha escura, visível à distância, com separação na excreção de fezes e de urina (Sick 1985).

A cavidade do coprodeo está separada do reto por uma evidente prega anular, que encerra um componente muscular circular, semelhante a um esfíncter. O urodeo é o mais curto dos três componentes da cloaca. O proctodeo, em sua linha média recebe a abertura da bolsa cloacal. Esta organização também é descrita em outras aves (Komárek 1970). Os nossos achados possuem semelhança com os citados acima, sendo que o proctodeo é a maior região da cloaca.

Na cloaca nota-se a presença de uma musculatura espessa, envolvendo as cartilagens do falo proximal, formando uma estrutura compacta, mas com grande capacidade de distensão. Quando a cloaca está parcialmente evertida, durante a evacuação de grande acúmulo de fezes, o orifício da abertura cloacal é visível e circular (King 1981).

No presente trabalho observou-se que a mucosa da cloaca apresentou vilosidades curtas revestidas por epitélio pseudoestratificado. Observa-se também a túnica mucosa apoiada na túnica muscular lisa e abaixo desta, uma muscular esquelética, apresentando grande quantidade de vasos sanguíneos entre as túnicas musculares, resultados semelhantes aos relatos dos autores acima. O urodeu e o proctodeo da cloaca dos pássaros possuem um epitélio colunar simples, com numerosas células de cálice e são revestidas pelas criptas de Lieberkühn, sendo estas mais profundas no cólon e tornando-se progressivamente mais superficiais à medida que se dirigem para o coprodeo (Jhonson \& Skadhauge 1975).

Com relação ao falo, na ema é um órgão fibroso linfático localizado na parede ventral, no assoalho da cloaca, na região do proctodeo, ligeiramente à esquerda da linha mé- 
dia. O falo da ema possui dois pares de músculos que estão situados na sua porção ventral e que auxiliam na sustentação e retração do mesmo são eles, o músculo levantador do falo e retrator do falo, o mesmo foi observado por King (1981) que relatou a presença desses músculos.

O falo nas aves é análogo ao pênis dos mamíferos, mas não homólogo, e que se expõe com certa freqüência (Fowler 1991). No falo das aves não há uretra, sendo que este não possui função urinária como o pênis dos mamíferos (Sick 1985). Em algumas aves o falo é considerado pequeno, como por exemplo em galos (Waites 1970) e em perús. Nestes não ocorre intromissão, ao invés disso o sêmen é depositado na vagina por um falo engorgitado em contato com a cloaca evertida da fêmea (Sturkie 1986). Em contraste, em patos (McCracken 2000) e outros, o falo é um órgão vascularizado, espiralado com um sulco ejaculatório que pode ser protraído por músculos e por infiltração linfática e ser retraído por ligamentos cartilagíneos (Sturkie, 1986). Na ema o acasalamento é realizado através de penetração de órgão copulatório bem desenvolvido (Waites 1970, Fowler 1991).

Nas emas estudadas, em estado flácido, a parte flexível está alojada no interior da sua base, formando volumosas massas teciduais em formato esférico. No interior do falo existem pregas que são intumescidas por linfa que, durante a cópula, provavelmente, funcionam como um mecanismo que expõe e recolhe o mesmo, após a ereção. A base esta composta por duas porções rígidas e o ápice do falo apresenta-se exteriorizado em ereção. A porção flácida do falo é constituída por um tubo que se insere na base da porção rígida. Fowler (1991) descreveu que as ratitas possuem dois diferentes tipos de falo. Nas emas e nos emús especificamente, assim como observado neste trabalho, um falo intromitente, com uma cavidade e uma estrutura em forma de luva, parcialmente invertida, é observado.

Segundo Góes (2004) o falo das emas, mede 3,0cm de comprimento por $7 \mathrm{~cm}$ de largura (em repouso). No presente trabalho o falo em exposição forçada chega a medir 14 $\mathrm{cm}$ de comprimento, ou seja, com a porção intromitente exposta. Quando relaxado, permanece contido em uma bolsa (como um dedo de luva), sob a mucosa desta região. Aproximadamente metade desta cavidade cega everte durante a ereção, para alongar o falo, porém, uma fixação na base da cavidade evita a eversão completa. Há um sulco fálico que direciona o sêmem para dentro da cloaca da fêmea, este sulco fica no dorso do falo. Knight et al. (1970) e Nickel et al. (1977) citaram que as ratitas, cisnes e algumas aves possuem um órgão copulatório, com mais ou menos $8 \mathrm{~cm}$ (pato) ou $10 \mathrm{~cm}$ (no cisne), cuja ereção ocorre por um fluxo de linfa aprisionado no seu interior, que é produzida por um par de cavidades situadas na base do pênis. Também descreveram que a ereção dos corpos do falo ocorre devido a secreção de linfa (fluído seminal), oriunda das cavidades paracloacais. Nos patos o falo é intromitente, cavidade e canais linfáticos são visíveis (Randal \& Reece 1996) e em algumas espécies, como é o caso do pato argentino Oxyura vittata, o penis pode atingir cerca da metade do comprimento corporal da ave (McCracken 2000).

Os resultados histológicos sugerem que, na ema, esse mecanismo linfático é responsável pela ereção, uma vez que foram observados vários vasos linfáticos dispersos no tecido conjuntivo frouxo do falo, confirmando a afirmação dos autores acima. A presença de um epitélio com conteúdo PAS+ no sulco fálico sugere secreção de glicoproteínas neutras para, possivelmente, ser adicionado ao sêmen no momento que este passa por este sulco durante a ejaculação, com função de lubrificar ou nutrir os espermatozóides.

Os dados discutidos demonstram que as emas possuem muitas semelhanças morfológicas com as aves em geral e em especial com os avestruzes e os emus, devido a sua proximidade evolutiva. Novos estudos morfológicos são necessários para confirmar o período de início da maturação dos órgaos genitais, as influências do fotoperíodo, as possíveis variações em diferentes regiões climáticas e geográficas e outras relacionadas com aspectos reprodutivos das emas.

\section{CONCLUSÕES}

Os órgãos genitais masculinos da ema estão representados pelos testículos, epidídimos e ductos deferentes com semelhanças anatômicas com as demais aves.

A ema possui um falo distinto intromitente, semelhante ao falo do emu, porém, diferente do avestruz, que não possui a porção intromitente e uma cloaca com três regiões distintas.

\section{REFERÊNCIAS}

Aire A. \& Soley J.T. 2000. The surface features of the epithelial lining of the ducts of the epididymis of the ostrich (Struthio camelus). Anat. Histol. Embryol. 29(2):119-126.

Aires A.T. 1979. Micro-stereological study of the avian epididymal region. J. Anat. 129:703-706.

Aires A.T. 1982. Surface morphology of the ducts of the epididymal region of the drake (Anas platyrhynchos) as reveled by scanning and transmission electron microscopy. J. Anat. 135(3):513-520.

Artoni S.M.B., Manoel H.L., Carvalho T.L.L., Orsi A.M. \& Stefanini M.A. 1999. Avaliação morfométrica da área do epidídimo e dos dúctulos eferentes e ductos epididimários da codorna doméstica, no decorrer do ano. Braz. J. Vet. Res. Anim. Sci. 36(6):283-289.

Bakst M.R. 1998. Scaning electron microscopy of the oviductal mucosa apposing the hen ovum. Poult. Sci. 57:1065-1069.

Baumel J.J., King A.S., Lucas A.M., Breazile J.E. \& Evans H.E. 1979. Nomina Anatomica Avium. Academic Press, London.

Bell D.J. \& Freeman B.M. 1971. The male in reproduction fowl, p.14121443. In: Ibid. (Eds), Physiology and Biochemistry of the Domestic Fowl. Vol.3. Academic Press, London.

Benez S.M. 1998. Aves: criação, clínica, teoria e prática. Robe, São Paulo.

Budras K.D. \& Meier U. 1981. The epididymis and its development in ratite bird (Emu, Ostrich, Rhea). Anat. Embryol. 162:281-299.

Clulow J. \& Jones R.C. 1982. Production, transport, maturation, storage and survival of spermatozoa in the male Japanese quail, Coturnix coturnix. J. Reprod. Fertil. 64:259-266, 
Codenotti T.L. \& Alvarez F. 1997. Cooperative breeding between males in the greater rhea Rhea americana. IBIS 139:568-571.

Dunnig J. \& Belton W. 1993. Aves silvestres do Rio Grande do Sul. $3^{\text {a }}$ ed. Fundação Zoobotânica do Rio Grande do Sul, Porto Alegre, p.22-23.

Fowler M.E. 1991. Comparative clinical anatomic of ratites. J. Zoo Wildl. Med., 22(2):204-227.

Friedmann H. 1927. Testicular asymmetry and sex ratio in birds. Biol. Bull. Woods Hole 52:197-207.

Froman D.P. \& Kirby T.D. 2004. Reprodução em aves, p.207-242. In: Hafez E.S.E. (Ed.), Reprodução Animal. $7^{\mathrm{a}}$ ed. Manole, São Paulo.

Giannoni M.L. 1996. Emas e avestruzes: uma alternativa para o produtor rural. Funep, Jaboticabal. 49p.

Góes P.A.A. 2004. Características reprodutivas de emas machos (Rhea americana) criadas em cativeiro no Estado de São Paulo. Dissertação de Mestrado em Reprodução Animal, Faculdade de Medicina Veterinária e Zootecnia, Universidade de São Paulo, São Paulo. 79p.

Gray J.C. 1937. The anatomy of the male genital ducts in fowl. J. Morphol. 60:393-405.

Hemberger M.Y., Hospes R. \& Bostedt H. 2001. Semen collection, examination and spermiogram in ostriches. Reprod. Domest. Anim. 36:241-243.

Hess R.A., Thurston R.J. \& Biellier H.V. 1976. Morphology of the epididymal region and ductus deferens of the turkey (Meleagris gallopavo). J. Anat. 122:241-452.

Hicks-Alldredge K.D. 1996. Ratite reproduction, In: Tulle T.N. \& Shane S.M. (Eds), Ratite Management, Medicine and Surgery. Krieger Publishing Company, Malabar. 188p.

Hodges R.D. 1974. The Histology of the Fowl. Academic Press, New York, p.300-316.

Johnson O.W. \& Skadhauge E. 1975. Structural-functional correlations in the kidneys and observations of colon and cloacal morphology in certain Australian birds. J. Anat. 120:494-505.

King A.S. 1981. Phallus, p.107-147. In: King A.S. \& McLelland J. (Eds), Form and Function in Birds. Vol.2. Academic Press, London.

King A.S. 1986. Aparelho urogenital das aves, p.1813-1828. In: Getty R. (Ed.), Sisson and Grossman's, Anatomia dos Animais Domésticos. Vol.2. Interamericana, Rio de Janeiro.

King A.S. \& McLelland J. 1984. Birds: Their structure and function. Baillière Tindall, London, p.5-139.

Knight C.E. 1970. The anatomy of the structures involved in the erection-dilution mechanism in the male domestic fowl. $\mathrm{PhD}$ thesis, Michigan State University.

Komárek V. 1970. Growth and differentiation of the follicles in the postnatal development of the chicken. Acta Vet. 39:11-16.

Lake P.E. 1957. The male reproductive tract of the fowl. J. Anat. 91:116129.
Lake P.E. 1981. Male genital organs, p.2-61 In: King A.S. \& McLelland J. (Eds), Form and Function in Birds. Vol.2. Academic Press, London.

Macari M. \& Júnior A.B. 2000. Doenças das Aves. Fundação Apinco de Ciências e Tecnologia Avícola, Campinas, p.81-129.

Malecki I.A., Martin G.B. \& Lindsay D.R. 1997. Semen production by the emu (Dromaius novaehollandiae). 2. Effect of collection frequency on the production of semen and spermatozoa. Poult. Sci. 76:622626.

Marvan F.R. 1968. Postnatal development of the male genital tract of Gallus domesticus. Anat. Histol. 124:442-463.

McCracken K.G. 2000. The $20-\mathrm{cm}$ spiny penis of the argentine lake duck (Oxyura vittata). Auk 117:820-825.

Munro S.S. 1938. Functional changes in fowl sperm during their passage through the excurrent ducts of the male. J. Exp. Biol. 79:7179.

Nickel R., Schummer A. \& Seiferle E. 1977. Anatomy of the Domestic Birds. Vol.1. $4^{\text {th }}$ ed. Verlag Paul Parey, Berlin. 518p.

Olson S.L. 1983. Lessons from a fligthless Ibis. Natural History 92:4041.

Ozegbe P.C., Kimaro W., Madekurozwa M.-C., Soley J.T. \& Aire T.A. 2010. The excurrent ducts of the testis of the emu (Dromaius novaehollandiae) and ostrich (Struthio camelus): Microstereology of the epididymis and immunohistochemistry of its cytoskeletal Systems. Anat. Histol. Embryol. 39(1):7-16.

Randal C.J. \& Reece R.L. 1996. Avian Histopathology. Mosby-Wolfe, London, p.232.

Romer A.S. \& Parsons T.S. 1985. Anatomia Comparada dos Vertebrados. $5^{\mathrm{a}}$ ed. Atheneu, São Paulo. 559p.

SAS Institute Inc. 1999. Release 9.1.3. Statistics Analysis System. SAS Institute Inc., Cary.

Sick H. 1985. Brazilian Ornitopatology. Nova Fronteira, Rio de Janeiro, p.168-171.

Simões K., Orsi A.M., Artoni S.M.B., Cruz C., Schimming B.C. \& Pinheiro P.F.F. 2004. Structural features of the epididymal region of the domestic duck (Anas plathyrynchos). Braz. J. Vet. Res. Anim. Sci. 41:92-97.

Sturkie P.D. 1986. Avian Physiology. $4^{\text {th }}$ ed. Springer-Verlag, New York.

Tingari M.D. 1971. On the structure of the epididymal region and ductus deferents the domestics fowl (Gallus domesticus). J. Anat. 109:423435.

Viegas K.A.S. 2004. Contribuição ao estudo morfológico do ducto deferente de codorna doméstica (Coturnix coturnix) da variedade italiana: estrutura, histofisiologia e possíves variações sazonais ao longo do ano. Dissertação de Mestrado em Anatomia, Faculdade de Medicina Veterinária e Zootecnia, USP, São Paulo. 95p.

Waites G.M.H. 1970. Temperature Regulation and the Testis. Academic Press, New York, p.241-279. 